\title{
Strike-slip motion of a mega-splay fault system in the Nankai oblique subduction zone
}

\author{
Takeshi Tsuji $1^{*}$, Juichiro Ashi ${ }^{2}$ and Yasutaka Ikeda ${ }^{3}$
}

\begin{abstract}
We evaluated the influence of the trench-parallel component of plate motion on the active fault system within the Nankai accretionary wedge from reflection seismic profiles, high-resolution seafloor bathymetry, and deep-towed sub-bottom profiles. Our study demonstrated that a large portion of the trench-parallel component of oblique plate subduction is released by strike-slip motion along a fault located just landward of and merging down-dip with a mega-splay fault. The shallow portion of the splay fault system, forming a flower structure, seems to accommodate dominant strike-slip motion, while most of the dip-slip motion could propagate to the trenchward décollement. Numerous fractures developed around the strike-slip fault release overpressured pore fluid trapped beneath the mega-splay fault. The well-developed fractures could be related to the change in stress orientation within the accretionary wedge. Therefore, the strike-slip fault located at the boundary between the inner and outer wedges is a key structure controlling the stress state (including pore pressure) within the accretionary prism. In addition, the strike-slip motion contributes to enhancing the continuous mega-splay fault system (outer ridge), which extends for approximately $200 \mathrm{~km}$ parallel to the Nankai Trough.
\end{abstract}

Keywords: Strike-slip fault; Mega-splay fault; Nankai Trough; Oblique subduction; Stress boundary

\section{Background}

At the Nankai Trough, the Philippine Sea Plate subducts beneath the Eurasian Plate at a convergence rate of approximately 4.1 to $6.5 \mathrm{~cm} /$ year and at an azimuth of $300^{\circ}$ to $315^{\circ}$ (as indicated by the black arrows in Figure 1; Seno et al. 1993; Ito et al. 1999; Miyazaki and Heki 2001). Because the trench-normal direction at the Nankai Trough off Kii Peninsula is approximately $330^{\circ}$ to $345^{\circ}$, the convergence vector between these two plates deviates approximately $15^{\circ}$ to $45^{\circ}$ counterclockwise from the direction normal to the trough axis. This subduction zone has repeatedly generated earthquakes in excess of M8 (Ando 1975). From the coseismic region estimated from seismic and tsunami inversions (e.g., Tanioka and Satake 2001; Kikuchi et al. 2003), the mega-splay fault off of Kumano, which branches upward from the plateboundary interface, may have experienced rupture during the 1944 Tonankai earthquake (Figure 2; Park et al. 2002). The traces of the mega-splay fault on the seafloor

\footnotetext{
* Correspondence: tsuji@i2cner.kyushu-u.ac.jp

${ }^{1}$ International Institute for Carbon-Neutral Energy Research (WPI-I2CNER),

Kyushu University, 744 Motooka, Nishi-ku, Fukuoka 819-0395, Japan

Full list of author information is available at the end of the article
}

are located at the transition zone that marks the seaward limit of the forearc basin and separates the outer accretionary wedge from the inner accretionary wedge (Figure 2; Kimura et al. 2007). At the transition zone, the outer ridge is well developed in the trench-parallel direction (Figure 1), where we observe a remarkable topographic lineament with a length of approximately $200 \mathrm{~km}$ (Park and Kodaira 2012). A recent drilling campaign of the Integrated Ocean Drilling Program (IODP) used borehole breakouts and core sample observations to show that the stress state (i.e., principal horizontal stress orientation) changes across the outer ridge (e.g., Tobin et al. 2009; Lin et al. 2010). Because the outer and inner wedges can behave differently during an earthquake cycle (Wang and $\mathrm{Hu}$ 2006), the transition zone functions as a stress boundary. Furthermore, the transition zone is a key region for evaluation of the potential of coseismic rupture propagation close to the trough axis, which may generate large tsunamis (Satake 1994; Gulick et al. 2011; Tsuji et al. 2013; Moeremans et al. 2014). Recent studies based on high-resolution seismic velocity and pore pressure distribution have demonstrated that a deep mega-splay fault continues to the seaward (trenchward) décollement and functions as a 


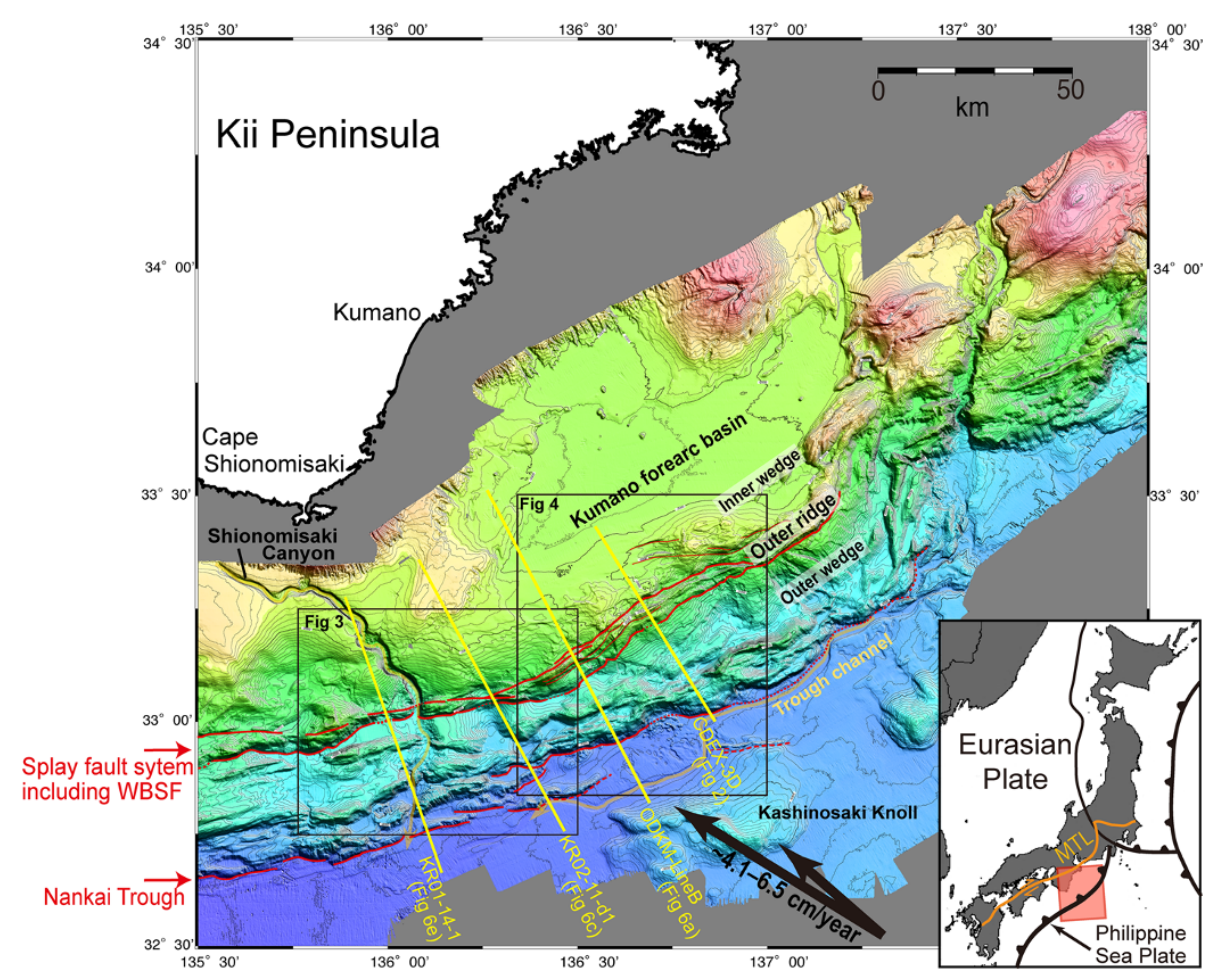

Figure 1 High-resolution seafloor topography of the Nankai Trough region off the Kii Peninsula. Red lines indicate the mega-splay fault system including the wedge boundary strike-slip fault (WBSF) and trough axis. Yellow lines indicate the locations of the seismic reflection survey lines shown in this paper. Black rectangles indicate the locations of the enlarged seafloor topography displayed in Figures 3a and 4a.

detachment fault (Figure 2; Kamei et al. 2012; Tsuji et al. 2014). Therefore, the function of the transition zone between the inner and outer wedges in the subduction system should be reconsidered.

Although the Philippine Sea Plate currently subducts obliquely beneath the accretionary prism in the Nankai Trough (Seno et al. 1993; Miyazaki and Heki 2001), it had subducted perpendicular to the trench until approximately 2 to $4 \mathrm{Ma}$ (Kimura et al. 2005; Takahashi 2006; Ikeda et al. 2009). The change in plate motion reactivated some faults within the accretionary wedge as strike-slip faults that could accommodate trench-parallel shear strain due to the oblique plate subduction. The Median Tectonic Line (MTL), located approximately $250 \mathrm{~km}$ landward from the trough axis, is well known as a large strike-slip fault that releases trench-parallel shear strain (Figure 1; Ikeda et al. 2009). A few recent studies (Ashi et al. 2007; Martin et al. 2010) have demonstrated that the lineament at the seaward edge of the Kumano forearc basin (just landward of seafloor trace of the mega-splay fault, see Figures 1 and 2) is the surface expression of an active strike-slip fault, and it can be interpreted to have resulted from strain partitioning. In other words, a portion of the trench-parallel component of oblique convergence is accommodated by the active right- slip fault at the wedge-forearc boundary (i.e., the transition zone). Indeed, borehole breakout analysis has demonstrated that the stress state within the accretionary wedge is a strike-slip regime in the outer ridge region (Chang et al. 2010). Because the strike-slip fault is located at the transition zone between the inner and outer wedges from the region off Shionomisaki to the region off Kumano (Figure 2), we call the strike-slip fault at the wedge boundary the 'wedge boundary strike-slip fault' (WBSF) in this study. Moore et al. (2009) named this fault system in the Kumano basin area (eastern side of our survey area; Figure 1) the Kumano basin edge fault zone. At the Ryukyu margin, the southern continuation of the Nankai Trough, Dominguez et al. (1998) showed that a strike-slip fault is developed at the outer ridge and that it accommodates some of the lateral components of oblique plate convergence.

Strike-slip motion within the accretionary wedge (e.g., along the WBSF) would influence the stress (and strain) state and interplate earthquake mechanisms. However, the degree of strain partitioning at the outer ridge has not been well quantified. Furthermore, the role of the strike-slip motion caused by oblique subduction in the evolution and kinematics of seismogenic mega- 

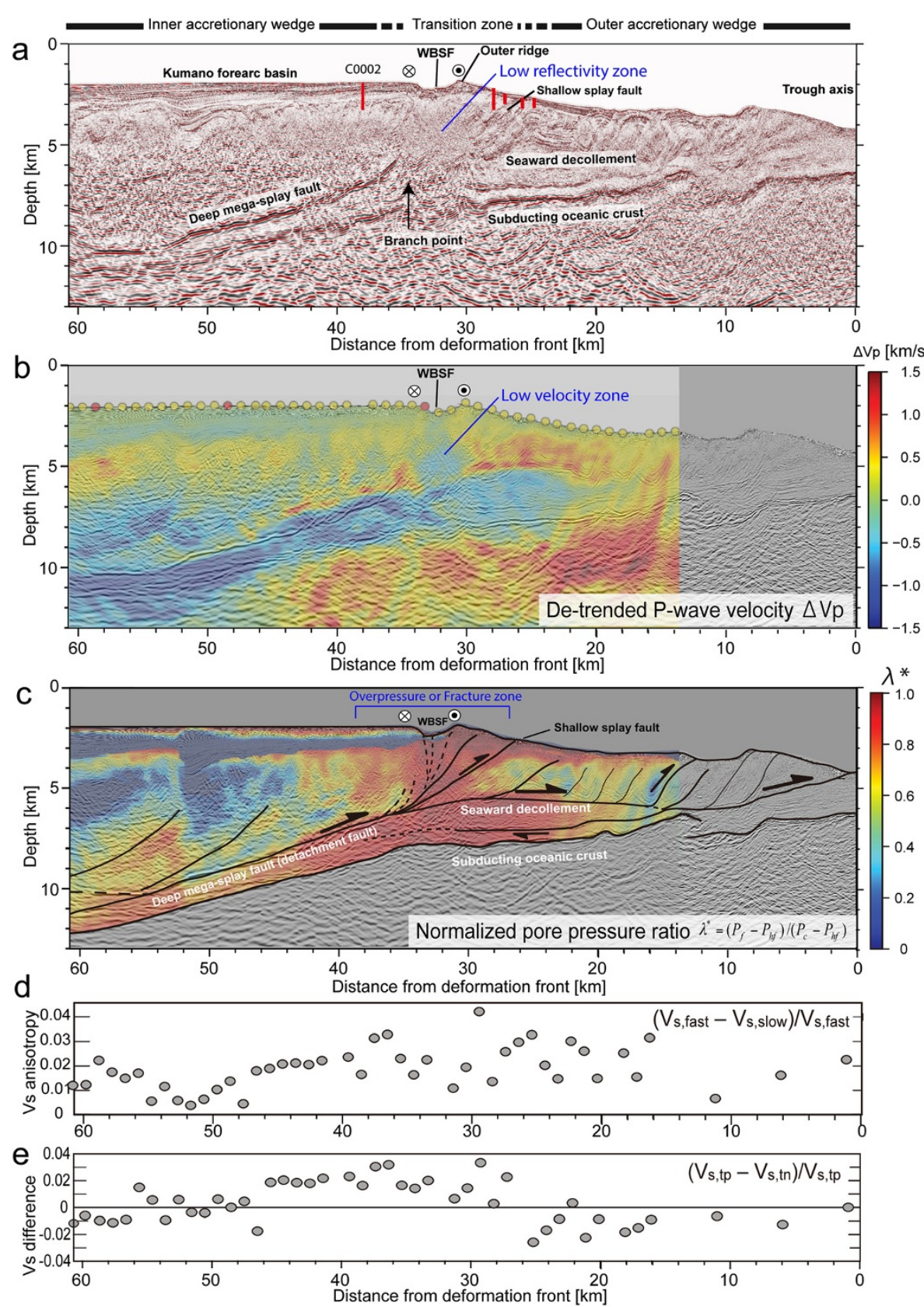

Figure 2 Seismic profile, P-wave seismic velocity, normalized pore pressure ratio, and S-wave velocity anisotropy. (a) Seismic profile across the Kumano transect (CDEX-3D). The locations of faults discussed in this paper (e.g., WBSF) are described in this panel. A low reflectivity zone occurs beneath the WBSF. (b) P-wave seismic velocity estimated from waveform tomography (WT; Kamei et al. 2012; Kamei et al. 2013) overlaid on the reflection seismic profile. The seismic velocity shown in this figure is de-trended from the dominant 1D velocity-depth trend defined in Kamei et al. (2013). Low P-wave velocity is observed within the accretionary prism beneath the WBSF. (c) Normalized pore pressure ratio (Tsuji et al. 2014), defined by $\lambda^{*}=\left(P_{\mathrm{f}}-P_{\mathrm{hf}}\right) /\left(P_{\mathrm{c}}-P_{\mathrm{hf}}\right)$ where $P_{\mathrm{c}}$ is the confining pressure, $P_{\mathrm{f}}$ is the pore pressure, and $P_{\mathrm{hf}}$ is the hydrostatic pressure. Overpressure and well-developed fractures cannot be distinguished, as described in Tsuji et al. (2014). (d) S-wave velocity anisotropy (Tsuji et al. 2011a), defined by $\left(V_{\text {s,fast }}-V_{\text {s,slow }}\right) / V_{\text {s,fast }}$ where $V_{\text {s,fast }}$ is the $S$-wave velocity for the fast-polarization direction and $V_{\text {s,slow }}$ is the velocity for the slow-polarization direction. (e) $\mathrm{S}$-wave velocity difference between trench-parallel direction $V_{s, t p}$ and trench-normal direction $V_{s, t n}$.

splay faults and in stress buildup within the accretionary wedge has not been fully explored. In this study, we estimate the extent of the strike-slip motion along the WBSF by integrating seismic-derived images and seafloor topography and evaluate the influence of the strike-slip fault on the stress state in the Nankai accretionary wedge and continuous mega-splay fault system. 


\section{Methods and results Seafloor bathymetry}

The detailed seafloor bathymetry was produced from SeaBeam multibeam echo sounder data that were acquired during cruises YK01-04, YK02-02, and YK03-03 (Figures 1 and 3). We did not examine the seafloor bathymetry of the Nankai Trough off Shikoku Island (the western side of our study area) because the seafloor in this area, including the mega-splay fault system, has been significantly deformed by seamount subduction (Gulick et al. 2004). Our high-resolution seafloor bathymetric map enabled us to trace the WBSF as a remarkable seafloor lineament (denoted by the red lines in Figure 1 and yellow arrowheads in Figure 3c). The fault trace continues for approximately $200 \mathrm{~km}$ in the trench-parallel direction and crosses a segmentation boundary between large interplate earthquake rupture areas in the Nankai Trough off Cape Shionomisaki (i.e., the boundary between the 1944 Tonankai earthquake and the 1946 Nankai earthquake rupture areas; Baba and Cummins 2005).
Shionomisaki Canyon was formed by deep erosion of the accretionary complex and crosscuts the east-west trending ridge structure (e.g., the outer ridge) (Figures 1 and 3). From the seafloor bathymetry around Shionomisaki Canyon, we identified an offset approximately $6 \mathrm{~km}$ long of the western sidewall (scarp) of the canyon (yellow dots in Figure $3 \mathrm{~b}$ ), which is likely to have been produced by rightlateral motion along the WBSF. Furthermore, the lineament caused by WBSF activity can be clearly observed at the bottom of the canyon (black arrow in Figure 3b). As sedimentary flow along the canyon intensively erodes the bottom and sidewalls of the canyon, the existence of the lineament at the bottom of the canyon indicates recent activity of the WBSF.

Along the length of the WBSF, a series of elongated ridges and narrow closed basins, which are interpreted to be pressure ridges and pull-apart basins, respectively, are hence suggestive of strike-slip motion (Ashi et al. 2007; Figure 1). At the trenchward edge of the forearc basin off Kumano (around the WBSF), the outer ridge is significantly developed (Figures 3c, 4a). High-resolution
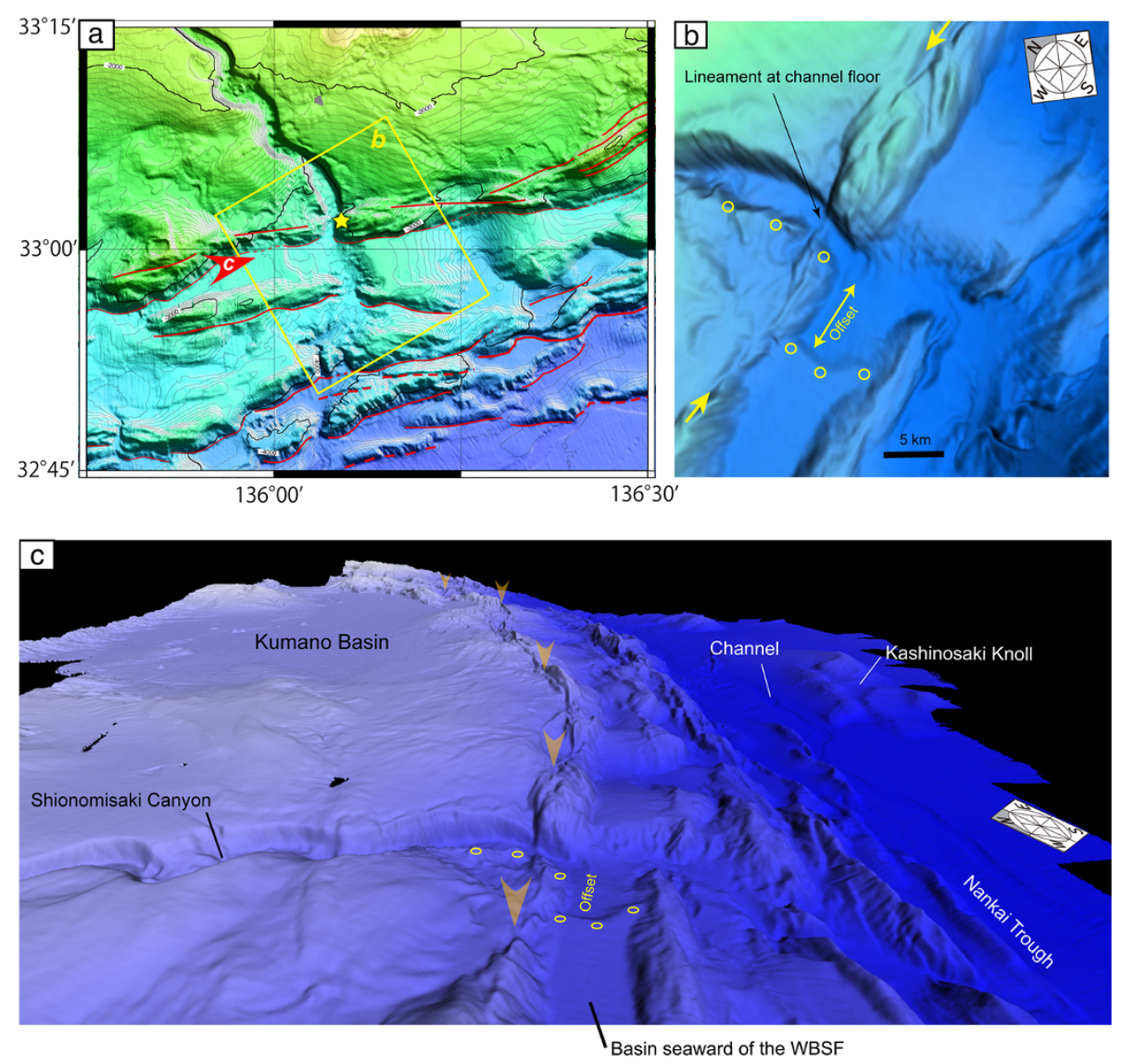

Figure 3 Enlarged seafloor bathymetry, offset of the canyon sidewall, and 3D seafloor bathymetry. (a) Seafloor bathymetry around Shionomisaki Canyon. The locations of cold seeps are denoted by the yellow star (Anma et al. 2011). (b) Offset of the canyon sidewall due to strike-slip (yellow dots). (c) 3D seafloor bathymetry showing outer ridge and WBSF (yellow arrowheads). The red arrowhead in panel (a) shows the sight angle of this figure. 

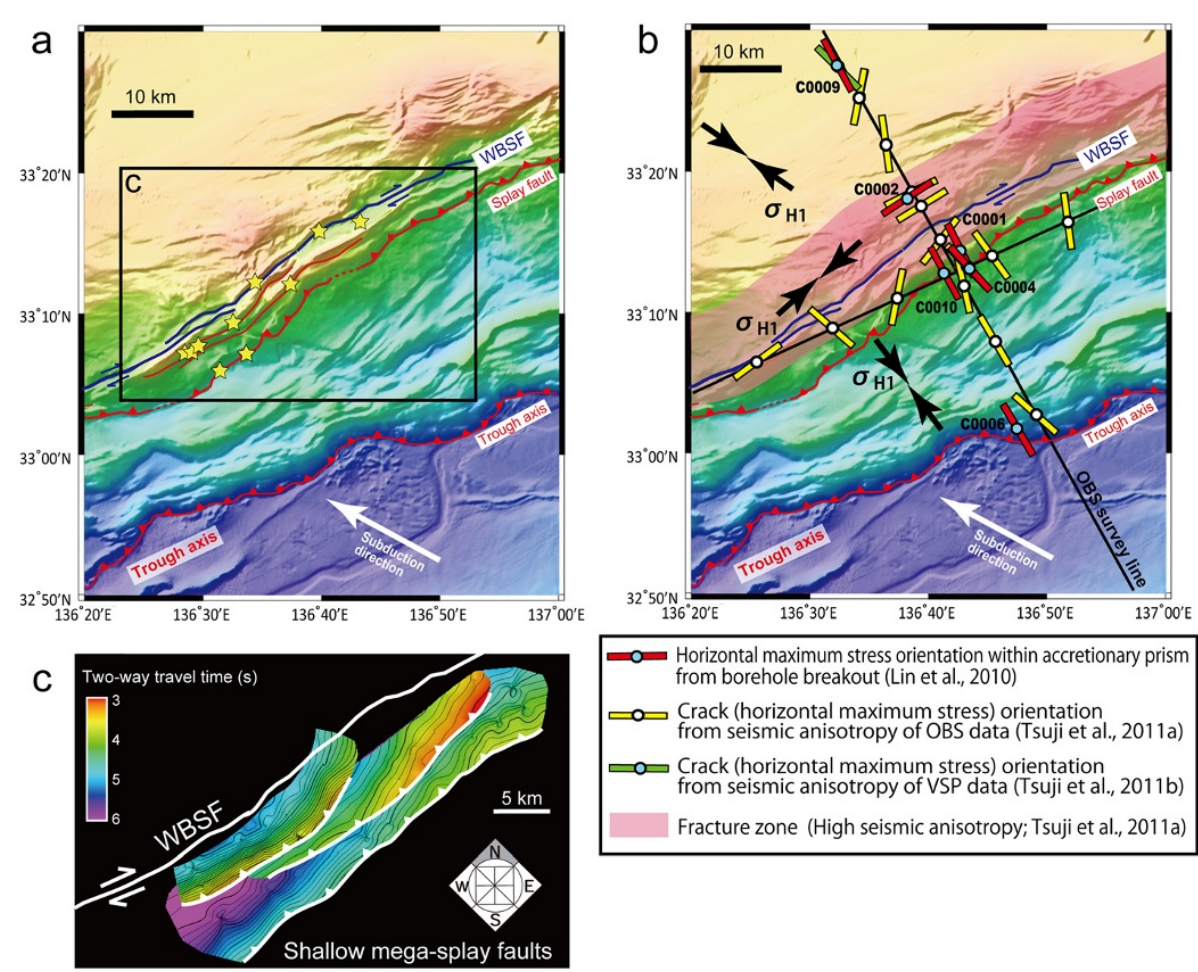

Figure 4 Seafloor traces of the mega-splay fault, horizontal maximum stress and fracture orientations, and geometry of fault planes. (a) Seafloor traces of the mega-splay fault at the outer ridge off Kumano. Red lines represent the landward-dipping splay faults and trough axis, and blue lines represent the WBSF. The outer ridge is developed between splay fault and WBSF. The locations of cold seeps are denoted by yellow stars (Ashi et al. 2002; Ashi et al. 2003). (b) Horizontal maximum stress orientation estimated from borehole breakout data (e.g., Lin et al. 2010) and fracture orientation estimated from OBS data (Tsuji et al. 2011a) and walk-around VSP data (Tsuji et al. 2011b). The horizontal principal stress changes at the well-developed fracture band (red-colored area). (c) Geometry of the fault planes of the dominant shallow branched mega-splay fault (seaward of WBSF) extracted from several 2D seismic profiles (ODKM-03).

seafloor bathymetry around the well-developed outer ridge was collected by a deep-tow side-scan sonar 'Wadatsumi', as shown in Figure 5 (Ashi et al. 2007). The highresolution seafloor bathymetry indicates the presence of approximately 3.5 - to $5-\mathrm{km}$-long linear depression landward of the outer ridge (yellow arrows in Figure 5). This depression is called 'the notch' (Martin et al. 2010). The notch is tectonically controlled, as is evidenced by a sharp linear fault scarplet developed in, or near the margin of, the notch. By changing the sight angle of the highresolution bathymetric maps, we determined the strike of the linear fault scarplet (yellow arrow in Figure 5b) and the sense of dip slip along it; the clearest fault trace located on the trenchward side of the pull-apart basin is downthrown on the north. Such topographic characteristics suggest that the notch is underlain by a negative flower structure caused by active trans-tensile faulting at depth (e.g., as discussed by Martin et al. 2010). However, the structure of the outer ridge as a whole seems to be a positive flower structure on a larger scale; therefore, the trans-tensile nature could be local due likely to local changes in the strike of the WBSF.

\section{Seismic data}

We used multi-channel seismic reflection data acquired by $3 \mathrm{D}$ seismic surveys and also used several $2 \mathrm{D}$ seismic surveys to delineate the mega-splay fault system in a wide area of the Nankai Trough. The 3D seismic data over the Nankai accretionary wedge off Kumano (Figure 2a) were acquired by M/V Nordic Explorer in 2006 (Moore et al. 2009). The $12 \mathrm{~km} \times 56 \mathrm{~km}$ survey area included both the inner and outer wedges. We applied 3D prestack depth migration to the 3D seismic data using a tomography-based approach. Because the seafloor multiple overlapped the structures of the transition zone (or outer ridge), the strong seafloor multiples were attenuated before migration processing. Detailed information about the data acquisition and processing procedures is described in Moore et al. (2009). To characterize the stress state and fractures around the transition zone, we further referred to P-wave velocity derived from waveform tomography (Figure 2b; Kamei et al. 2012, 2013, 2014), pore pressure distribution (Figure 2c; Tsuji et al. 2014), fast $\mathrm{S}$-wave velocity anisotropy (Figure $2 \mathrm{~d}$ ), and S-wave velocity difference between the trench-parallel direction and 

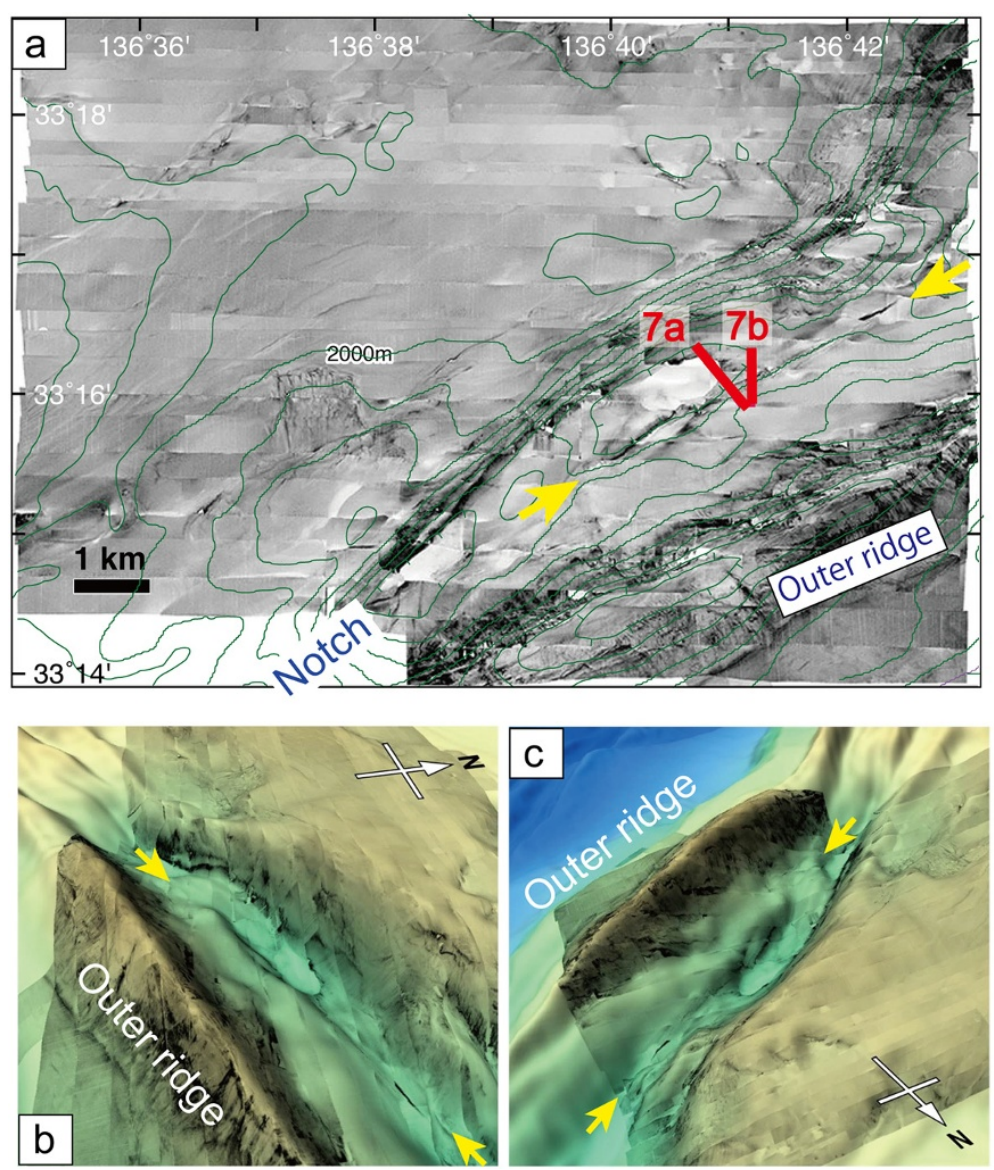

Figure 5 High-resolution seafloor topography derived from deep-tow side-scan sonar 'Wadatsumi'. (a) Map view of the high-resolution seafloor topography. Yellow arrows indicate seafloor traces of the strike-slip fault. Red lines indicate survey lines of the sub-bottom profiler. In panels (b) and (c), the angle of sight is different.

trench-normal direction (Figure 2e; Tsuji et al. 2011a). As abnormal pore pressure estimated from seismic velocity (Figure 2d) cannot be distinguished from open fractures (Tsuji et al. 2014), the estimated overpressured region has the potential to represent well-developed fractures.

To characterize the mega-splay fault system along its strike, we used several 2D seismic reflection data acquired across the mega-splay fault system. We used seismic data from two multi-channel seismic reflection surveys conducted by the R/V Kairei of JAMSTEC: KR0114 and KR0211 (yellow lines in Figure 1; Figure 6). These surveys employed an airgun array with a volume of approximately $200 \mathrm{~L}\left(12,000 \mathrm{in}^{3}\right)$ fired at $50-\mathrm{m}$ intervals and an approximately 5-km-long streamer with 204 receivers. We also used $2 \mathrm{D}$ multi-channel reflection data acquired during cruise ODKM-03 by the R/V Polar Princess in 2003, which employed a tuned airgun array with a total volume of approximately $70 \mathrm{~L}\left(4,240 \mathrm{in}^{3}\right)$ fired at 50-m intervals and a 6-km-long streamer with 480 channels. Data processing for the 2D seismic reflection data involved filtering, velocity analysis, stacking, deconvolution, and post-stack migration (Yilmaz and Doherty 2001). These 2D seismic profiles show the geological structures of the accretionary prism (inner and outer wedges) off Kumano (ODKM-B; Figure 6a), Cape Shionomisaki (KR01-14-1; Figure 6e), and their intermediate zone (KR02-11-d1; Figure 6c).

The deeper part of the mega-splay fault system $(>6 \mathrm{~km}$ below the seafloor) is well defined as a prominent single reflector on the analyzed seismic profiles off Kumano, as shown in Figures 2 and 6a,b (Park et al. 2002; Tsuru et al. 2005; Bangs et al. 2009; Moore et al. 2009). The seismic velocity derived from waveform tomography (Figure $2 b$ ) demonstrates that the footwall of the deep mega-splay fault has low P-wave velocity due mainly to an overpressured state and a lithology difference (Figure 2c; e.g., Tsuji et al. 2014). On the other hand, the deep mega-splay fault seems to branch trenchward from beneath the WBSF, but it becomes less reflective (Figure 2a) and has lower velocity contrast around the outer ridge (Figure 2b; Kamei 

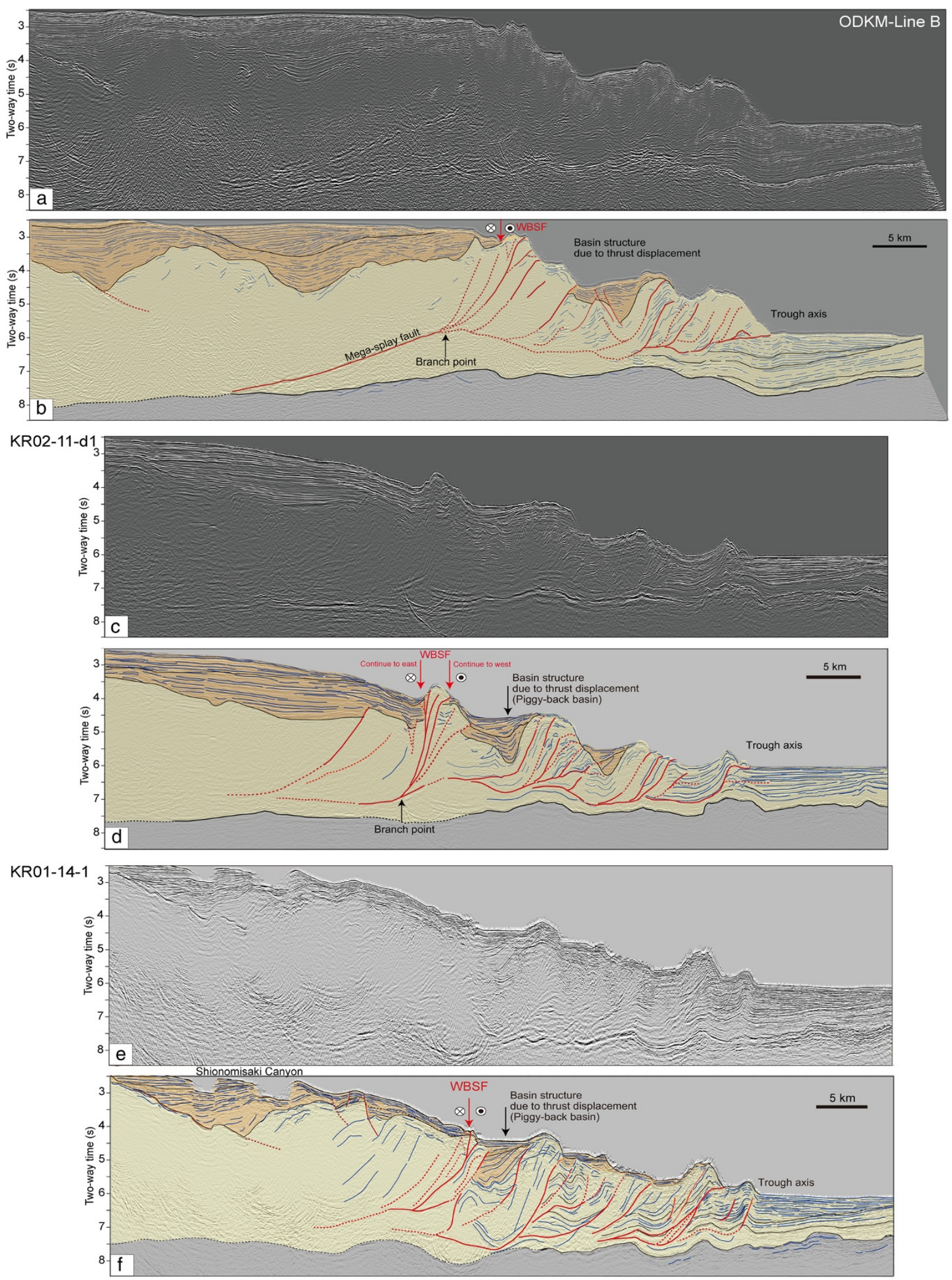

Figure 6 Three seismic profiles showing the WBSF and their interpretations. Original seismic reflection profiles of (a) ODKM-Line B, (c) KR02-11-d1 and (e) KR01-14-1. The locations of these seismic profiles are displayed in Figure 1. In the interpretation profiles (b, d, f), red hatched areas denote slope sediment. Yellow areas denote the accretionary wedge. Gray areas denote subducting oceanic crust. 
et al. 2012). Therefore, it is difficult to identify the geometry of the shallower part of the mega-splay fault system. In this study, we determined the detailed 3D geometries of the shallower parts of the branched faults from a dense 2D seismic profile (ODKM-03) partially using phase information from seismic signals (i.e., instantaneous phase; Taner et al. 1979; Tsuji et al. 2005). The extracted fault geometry is discontinuous and en echelon with faults branching trenchward from beneath the outer ridge (Figure 4a,c). These shallow discontinuous splay faults seem to merge into the deeper, single mega-splay fault at the transition zone (Figure 2). The WBSF could not be imaged clearly on the multi-channel seismic profiles, likely because the heterogeneous geological structures including fractures exclude coherent reflection events and because the dip angle of the WBSF is probably too steep to be imaged. The WBSF seems to form a flower structure (Ashi et al. 2007; Martin et al. 2010), although the relationship between the WBSF and the mega-splay thrust fault cannot be clearly revealed from reflection seismic profiles. Because the WBSF exists parallel to and close to the shallow branched mega-splay thrust fault, it seems likely that the WBSF and the mega-splay fault merge down-dip at the transition zone (black arrows in Figure 2).

The characteristics of the mega-splay fault and WBSF change at a point off Cape Shionomisaki (Figure 6c,e), where the WBSF intersects the rupture segment boundary between the 1944 Tonankai and 1946 Nankai earthquakes. However, the lineament associated with the WBSF exists continuously across the segment boundary. Off Cape Shionomisaki, the mega-splay fault does not have strong reflection amplitude, which indicates that the splay fault is not a well-developed boundary of pore pressure or lithology (Figure 6c,e). Instead, steeply dipping faults branch directly from the basal décollement that developed close to the sediment/crust interface, and it is difficult to distinguish the splay fault from the WBSF. Thus, it seems likely that the shallow branched splay fault itself has a strike-slip component and functions as the WBSF off Cape Shionomisaki (Figure 6d,f).

\section{Deep-tow sub-bottom profiler}

To reveal shallow geological structures associated with the WBSF, we acquired high-resolution profiles of sub-seafloor structures using a deep-tow sub-bottom profiler (Figure 7). Because a conventional sub-bottom profiler attached to a ship could not capture the detailed structures around the shallow part of the mega-splay fault system, we attached the sub-bottom profiler to a remotely operated vehicle (ROV). The ROV surveyed the pull-apart basin from a height of approximately $10 \mathrm{~m}$ above the seafloor (red lines in Figure 5a). The vertical resolution of these profiles is estimated at 10 to $15 \mathrm{~cm}$, which is significantly higher than the resolution of conventional sub-bottom profilers.
The high-resolution profiles show detailed geological structures (e.g., strata and minor faults) across the pullapart basin (Figure 7). The sedimentary sequence in the central part of the pull-apart basin (Figure 7c) is not significantly disturbed by faulting. Instead, the sedimentary sequence in the pull-apart basin laps onto the trenchward slope.

On the other hand, we observed deformation features associated with activity of the WBSF in the trenchward slope of the basin (Figure 7d). Because the reflectors showing layered structures are discontinuous in the horizontal direction, the sedimentary sequence is disrupted by several minor faults (denoted by red lines in Figure 7d). This fault trace is consistent with a seafloor lineament observed on the high-resolution seafloor bathymetry (denoted by the yellow arrow in Figure 5). Therefore, the lineament in the trenchward slope of the basin was caused by recent fault activities.

\section{Discussion}

\section{Strike-slip rate at the WBSF}

In this section, we approximately estimate the slip rate of the WBSF from the offset of Shionomisaki Canyon (Figure 3). First, we estimate a minimum rate of slip. The 6-km offset of the western sidewall of the canyon was caused by the cumulative right-slip on the WBSF. It is evident that the channel offset has been increasing progressively by incision of the continental slope since Shionomisaki Canyon was established. Therefore, the maximum age of the canyon offset is the age when the accretionary wedge front was at the present-day offset point. By considering the growth rate of the accretionary prism calculated mainly from the shape of the prism imaged on seismic profiles (Figures 2 and 6) and the thickness of incoming sediment (Westbrook 1994), we can approximately calculate the depositional age of the accretionary prism at the offset point at $20 \mathrm{~km}$ distance from the trough axis as 1.7 Ma. Anma et al. (2011) studied seafloor outcrop samples of the accretionary wedge at the offset region and estimated the depositional age at approximately $2 \mathrm{Ma}$ (yellow star in Figure 3a). The present mega-splay fault off Kumano was initially a frontal thrust at $1.95 \mathrm{Ma}$ (Strasser et al. 2009). These ages give the maximum age of the channel offset; therefore, the minimum rate of strike-slip along the WBSF can be calculated as approximately $3 \mathrm{~mm}$ /year by dividing the offset length by the age $(=6 \mathrm{~km} / 2 \mathrm{Ma})$. Because this rate is a minimum value, we estimate a more realistic slip rate using other information as follows.

Another estimation can be made on the basis of the local sedimentation rate. The seismic reflection profile across the offset region shows that a deep piggy-back basin has developed beneath the offset channel on the downthrown side of the mega-splay fault (Figure 6e,f). 

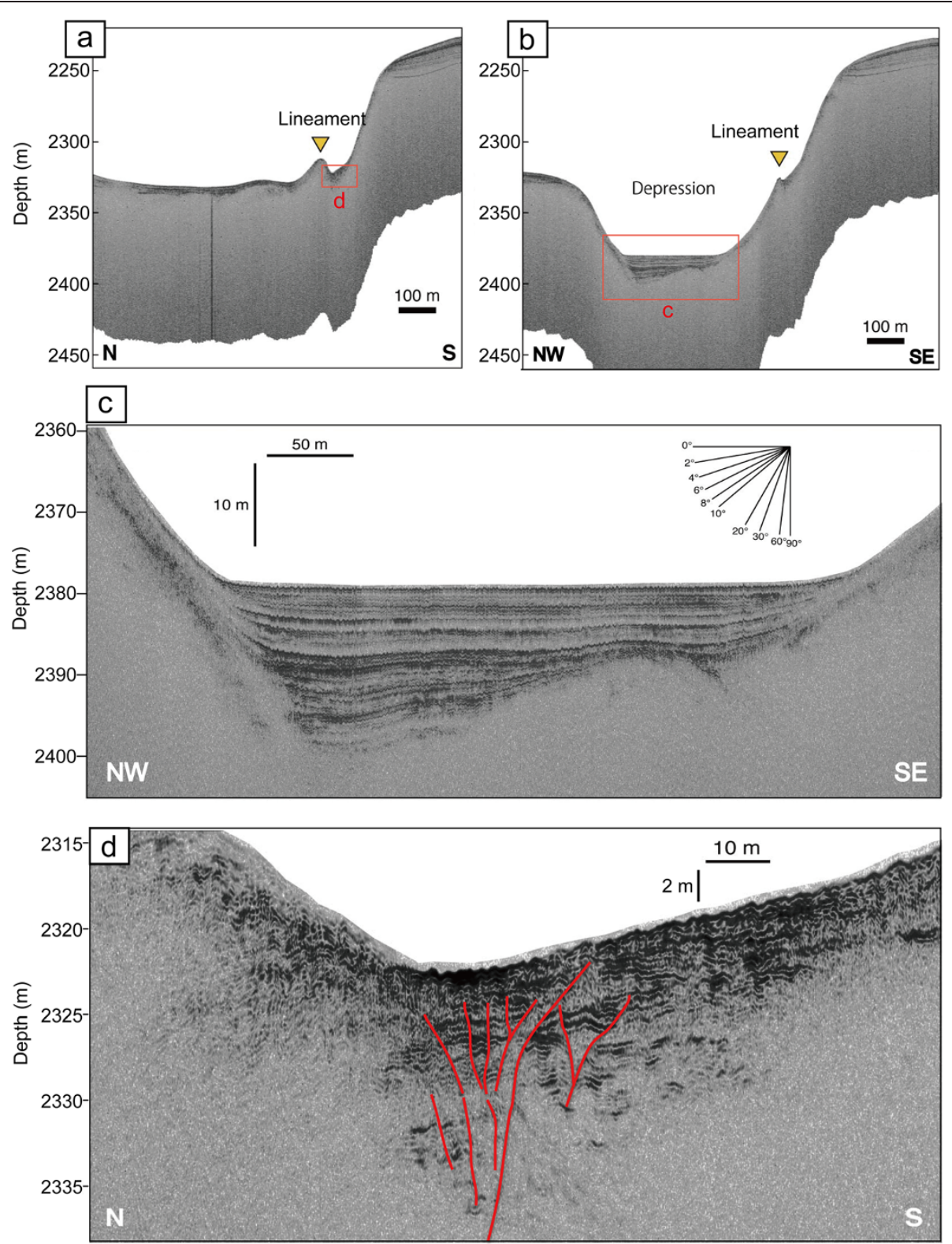

Figure 7 Profiles derived from the deep-tow sub-bottom profiler. $(\mathbf{a}, \mathbf{b})$ High-resolution profiles across the Notch. Yellow triangles indicate the lineament associated with the WBSF. Locations of these profiles are displayed in Figure 5a. (c, d) Enlarged profiles of the basin structure (notch) and the seafloor trace of the interpreted strike-slip fault, respectively.

The thickness of the basin fill derived from the upper slope is approximately $1,000 \mathrm{~m}$. The lower part of the basin fill becomes progressively tilted landward with depth (Figure 6f), while the upper basin fill (lying unconformably on the lower basin fill) does not. This indicates that the lower basin fill is coeval with, and the upper basin fill post-dates, activity of the trenchward imbricate thrust fault. On the other hand, the megasplay fault system has likely been active throughout the deposition of the basin fill because the basin-fill strata thicken toward and terminate against the mega-splay fault system. The deposition rate of the slope sediment in this piggy-back basin has not been estimated, but it could be high because of the considerable amount of sediment that can be supplied from Shionomisaki Canyon, which is one of the major supply routes of terrestrial sediment. Using the depth of the slope sediment beneath the offset deposits $(1,000 \mathrm{~m})$ at the landward side of the trough axis, the average deposition rate of the slope sediment can be estimated to be greater than $0.5 \mathrm{~mm} /$ year by dividing the sediment thickness (approximately $1,000 \mathrm{~m}$ ) by the age of the accretionary 
prism (approximately $2 \mathrm{Ma}$ ). Because the height of the channel wall (scarp) of the canyon at the offset point is approximately $150 \mathrm{~m}$ and because the present canyon center is almost the same depth (approximately $200 \mathrm{~m}$ deeper than the surrounding seafloor; Figure 3), the offset floor did not receive significant sediment during the $6-\mathrm{km}$ strike-slip movement. To preserve the $150-\mathrm{m}$ scarp of the previous canyon wall at $6 \mathrm{~km}$ from the canyon center with the high sedimentation environment (>0.5 mm/year), the WBSF would have had to slip $6 \mathrm{~km}$ in less than approximately $0.3 \mathrm{Ma}(=150 \mathrm{~m} / 0.5 \mathrm{~mm} /$ year). Therefore, we can approximately estimate the slip rate as $20 \mathrm{~mm} /$ year $(=6 \mathrm{~km} / 0.3 \mathrm{Ma})$. Although our estimation of the slip rate based on several assumptions (e.g., local sedimentation rate) contains large error, the slip rate of the WBSF is of similar order with the plate convergence rate. The slip rate would be faster than that of the landward MTL (approximately $5 \mathrm{~mm} /$ year), which is a large strike-slip fault that partitions oblique Philippine Sea Plate motion west of the Kii Peninsula and Shikoku Island (Ikeda et al. 2009).

The convergence vector between the Philippine Sea Plate and the Eurasian Plate deviates by approximately $35^{\circ}$ to $50^{\circ}$ counterclockwise from the perpendicular to the trench off Cape Shionomisaki (arrow in Figure 1; Seno et al. 1993; Miyazaki and Heki 2001). If the WBSF accommodates all the trench-parallel component of relative plate motion, then the rate of strike-slip on the WBSF would be $38 \pm 12 \mathrm{~mm} /$ year in the offset region off Cape Shionomisaki. Therefore, our slip rate estimation (approximately $20 \mathrm{~mm}$ /year) suggests that the WBSF at the outer ridge releases a large portion (approximately $52 \%)$ of the trench-parallel component of plate motion.

The change in the subduction direction of the Philippine Sea Plate could influence our slip rate estimation (described above). The Philippine Sea Plate was subducting beneath the Japanese islands in the NNW direction at $15 \mathrm{Ma}$ (Seno and Maruyama 1984; Takahashi 2006); this direction differs from the current plate motion direction (Miyazaki and Heki 2001; Ide et al. 2010). The time of the change in subduction direction has not been determined precisely, but it was probably between 2 and 4 Ma (e.g., Kimura et al. 2005; Takahashi 2006; Ikeda et al. 2009). Therefore, the slip rate estimated in this study (approximately $20 \mathrm{~mm} /$ year) is not influenced by the change in plate subduction direction.

Within the Kumano forearc basin sediment on the landward side of the WBSF, there does not appear to be a continuous strike-slip fault (Gulick et al. 2010). Therefore, the strike-slip motion has not been significant at the inner wedge area since the construction of the Kumano basin (approximately $2 \mathrm{Ma}$ ). Shear wave splitting analysis along the Kumano transect (Tsuji et al. 2011a) shows the highest seismic anisotropy around the
WBSF (approximately 4\%; Figure 2d), and the fast polarization of shear waves is in the trench-parallel direction (i.e., the strike of the WBSF; Figure 2e and yellow bars in Figure 4b). This seismic anisotropy suggests that fractures with trench-parallel orientations are well developed from the outer ridge to approximately $10 \mathrm{~km}$ landward of the WBSF (red zone in Figure 4b). The shallow overpressured zone (or lower velocity zone; Kamei et al. 2012; Tsuji et al. 2014) in the accretionary prism beneath the WBSF could also reflect the presence of open fractures or extensional faults around the WBSF (Figure 2c). Therefore, the strike-slip fault with intensive fractures could be observed only around the WBSF within our study area.

\section{Influence of strike-slip faulting on the stress state within the accretionary wedge}

The strike-slip motion and well-developed fractures along the WBSF must be related to the stress state (including pore pressure) within the accretionary wedge. The deep mega-splay fault landward of the transition zone off Kumano has been imaged as a single reflector with strong reflection amplitude (Figure 2; Park et al. 2002; Bangs et al. 2009), indicating a large contrast in seismic velocity (Tsuji et al. 2006; Kamei et al. 2012), which in turn originates from large pore pressure contrast or difference in lithology. Overpressured fluid may be trapped by a low-permeability barrier along the deep mega-splay fault (e.g., Brown et al. 1994). On the other hand, the mega-splay fault branches into several fault planes on the seaward side of the transition zone (Figures 2 and 6), and the reflection amplitudes of the shallow splay faults are lower. Therefore, the pore pressure contrast or total displacement along the shallower thrusts should be small compared with the deep megasplay fault. Fault branching may be related to the decreasing pore pressure contrast. These intensive fractures along the WBSF could release the overpressured pore fluid trapped by the low-permeability barrier along the megasplay fault. Indeed, we found several cold seepages at the seafloor traces of the mega-splay fault and WBSF (Figures 3a and 4a; Ashi et al. 2002; Ashi et al. 2003; Toki et al. 2004; Anma et al. 2011), suggesting leakage of overpressured fluid along the well-developed fractures.

Borehole breakouts and core sample observations have revealed the change in the stress state (principal horizontal stress orientation) across the WBSF off the Kumano area (e.g., Tobin et al. 2009; Lin et al. 2010; Figure $4 \mathrm{~b}$ ). The maximum principal horizontal stress is perpendicular to the trench seaward of the WBSF and parallel to it landward of the WBSF, and it changes again further landward to become nearly parallel to plate convergence (red bars in Figure 4b). Therefore, the principal stress is locally oriented in the trench-parallel direction 
around the WBSF (red zone in Figure 4b). These variations in stress orientation could be hypothetically explained by static stress variations during the earthquake cycle (i.e., dynamic Coulomb wedge theory; Wang and $\mathrm{Hu}$ 2006). In addition to this interpretation, the stress change could be partially influenced by strain partitioning because strike-slip motion on the WBSF would release trenchparallel shear stress of the outer wedge caused by oblique plate subduction. Therefore, the strike-slip motion realizes the trench-normal principal horizontal stress in the outer wedge (e.g., Site C0001) and inner wedge (Site C0009).

It is difficult to explain the drastic change (approximately $90^{\circ}$ ) in stress orientation within the short distance around the WBSF (approximately $10 \mathrm{~km}$; red bars in Figure 4b) because the continuous lithology does not allow significant change in principal stress orientation within a short distance (does not allow change in trench-normal stress). Although this anomalous stress state at the WBSF cannot be clearly explained, we have some interpretations as follows. At the seaward edge of the Kumano forearc basin (i.e., transition zone), the accretionary prism is locally bent (Figure 2). The surface of the inner accretionary wedge beneath the forearc basin has a landward dip of approximately $2^{\circ}$, whereas the outer wedge has a seaward dip of approximately $5^{\circ}$. The local bending of the accretionary prism generates extensional stress within the shallow accretionary prism at the transition zone. Gravitational instability of such a bathymetric high at the transition zone may further generate extensional stress. The extension originates open fractures oriented in the trench-parallel direction, as estimated by seismic anisotropy (Figure $2 \mathrm{~d}$,e). The pore pressure distribution, which is also interpreted as fracture intensity (Figure 2c; Tsuji et al. 2014), further suggests that open fractures are distributed widely around the WBSF. The apparent fracture zone around the WBSF mechanically divides the accretionary wedge into outer and inner wedges and may function as a stress (and strain) boundary within the accretionary prism.

Furthermore, studies on dislocation fault models have indicated that stress discontinuity across a fault can occur where slip decreases or increases along the fault plane (e.g., Maruyama 1969). Conversely, if slip is uniform over the fault, then the stress field is continuous across it. Moreover, from analogy with the dislocation theory, the changes in slip (i.e., distributed dislocation) produce stress concentration on the fault plane (e.g., Maruyama 1969), which would result in plastic deformation or the development of a fracture zone along the fault. Therefore, the significant stress change could occur at the intensive fracture zone along the WBSF. Furthermore, a stress anomaly could occur at the edge of the coseismic deep mega-splay fault if coseismic rupture from the deep mega-splay fault is abruptly terminated there.
Although we have some other interpretations for the significant change in stress orientation (e.g., extension at the hanging-wall side of the seismogenic fault), but cannot clarify a dominant mechanism, future deep drilling could provide new insights into the abrupt change in stress state.

On the seismic profile off Cape Shionomisaki, on the other hand, the accretionary wedge is not significantly bent, but is separated by a deep piggy-back basin filled with thick slope sediments on the seaward side of the WBSF (Figure 6d,f). The strike-slip motion off Cape Shionomisaki is larger than that off the Kumano region because of the smaller angle between the strike of the WBSF and the subduction direction. Although the stress state off Cape Shionomisaki has not been measured directly, the stress (and strain) discontinuity across the WBSF could be enhanced by the marked change in rock properties due to soft slope sediment and many dislocation planes (fractures).

Strike-slip motion of the continuous mega-splay fault system Discontinuous and branching characteristics are observed in the shallower part of the splay fault on the trenchward side of the outer ridge (Figures $4 \mathrm{c}$ and 6). Thrust faults generally have discontinuous features along strike and generally change geometry over time (e.g., Yamada et al. 2013) as the result of processes such as segment linkage (Cartwright et al. 1995), propagation across barriers (Ellis and Dunlap 1988), and subsequent deformation after fault formation (e.g., Yamada et al. 2006). However, the mega-splay fault system as a whole (including the WBSF) continues for as long as $200 \mathrm{~km}$ in an east-west direction along the trench axis and functions as a transition zone between the inner and outer accretionary wedges (Figures 1 and 3c). Such good continuity of the mega-splay fault system could be explained by strike-slip motion along the WBSF caused by oblique plate subduction. After the mega-splay fault was initiated and the Coulomb wedge was allowed to thicken, the later strike-slip motion emphasized the continuous mega-splay fault in the trench-parallel direction. Analog experiments related to the subduction process demonstrate that strike-slip faults that are continuous for a long distance, like the WBSF, tend to develop in oblique subduction regimes (e.g., Martinez et al. 2002). The continuous mega-splay fault system enhanced by strike-slip motion and its down-dip extension could be the source of a large interplate earthquake, the rupture area of which may extend across the segment boundary between the 1944 Tonankai and 1946 Nankai earthquakes (Park and Kodaira 2012).

Although the WBSF potentially has large strike-slip displacement (approximately 52\% of strain partitioning), the slip partition of the shallow portion of the megasplay fault on the trenchward side of the outer ridge is only approximately $1.5 \%$ to $2.5 \%$ of the total plate 
convergence in the dip direction (Kimura et al. 2011). The lower contribution of strain partitioning for the dip direction suggests that most of the dip-slip component along the deep mega-splay fault propagates to the seaward décollement or produces internal deformation of the accretionary wedge. Indeed, a seismic velocity contrast (or pore pressure contrast) is not observed on the shallow splay fault, whereas a low-velocity zone is observed widely beneath the WBSF and can be interpreted as a well-developed fracture (Figure 2a; Tsuji et al. 2014). Therefore, the dominant slip mechanism of the shallow portion of the mega-splay fault system around the outer ridge, including the WBSF, could be strike-slip, especially off Cape Shionomisaki where the trenchparallel component is dominant. From seafloor bathymetry, the WBSF and the outer ridge as a whole could be interpreted to be a positive flower structure (Figure 8). The en echelon shallow branched thrusts extracted from seismic data (Figure 4c) can be interpreted as part of this positive flower structure (Figure 8). Because positive flower structures typically include thrusts with minor displacement surrounding a main strike-slip fault (e.g., Hornafius et al. 1986; Murphy and Fuis 2010) and because the shallow splay fault was much more active in the past (approximately $2 \mathrm{Ma}$ ), only dip-slip features are observed in core samples of the shallow branched megasplay fault (Ashi et al. 2008).
At plate convergent margins, where the trench-parallel component of plate motion is dominant (e.g., the Sumatra subduction zone; McCaffrey et al. 2000; Subarya et al. 2006), long, continuous strike-slip faults in the trenchparallel direction develop mainly because (1) a strike-slip fault tends to be linear and continuous along the strike, based on the simple geometrical postulate that a fault plane should be smooth in the slip direction, and (2) rupture energy along a steep strike-slip fault is lower than that along a reverse fault with a low dip angle (and large rupture plane) (Woodcock 1986). Therefore, the WBSF has played an essential role in the evolution of the long and continuous mega-splay fault (outer ridge) system as well as in strain partitioning in the plate convergent zone.

\section{Conclusions}

We characterized a strike-slip fault associated with oblique subduction from reflection seismic profiles, seafloor bathymetry, and deep-towed sub-bottom profiles in the Nankai Trough off the Kii Peninsula. The results provide new insights into the influence of strike-slip motion on mega-splay fault systems.

Our primary conclusions follow:

(1) From the seafloor bathymetry of Shionomisaki Canyon, we could approximately estimate the strike-slip rate along the WBSF. The majority of

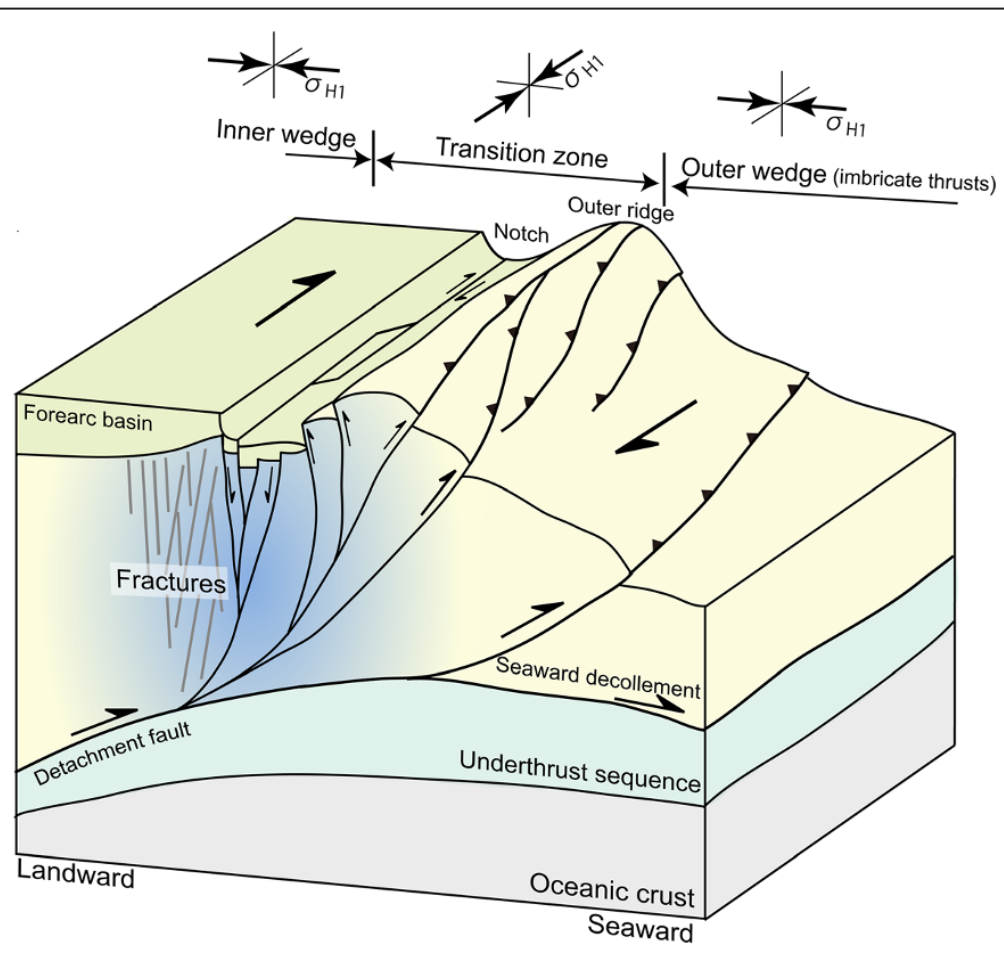

Figure 8 Schematic image of the WBSF region (or transition zone from inner wedge to outer wedge). The blue region indicates the well-developed fracture zone. 
strain due to the oblique subduction is released at the WBSF.

(2) The strike-slip motion caused by oblique plate subduction could have contributed to the generation of the continuous mega-splay fault system in the trench-parallel direction.

(3) Overpressured fluid is released at the well-developed fracture zone along the WBSF, suggesting that several faults could be branched at the seaward side of the WBSF.

(4) The horizontal principal stress changes completely within the intensive fracture zone along the WBSF off the Kumano area.

(5) The shallower portion of the mega-splay fault system including the WBSF could function mainly as a strike-slip fault. The majority of dip slip could propagate from the deep mega-splay fault of the inner wedge to the seaward décollement of the outer wedge.

\section{Competing interests}

The authors declare that they have no competing interests.

\section{Authors' contributions}

$\Pi$ carried out the data analysis and interpretation and drafted the manuscript. JA acquired the seafloor bathymetry and subbottom profiler data and carried out the interpretation for these data. YI carried out the interpretation for the seafloor bathymetry and seismic data. All authors joined the interpretation and discussion for the strike-slip motion along the mega-splay fault system. All authors read and approved the final manuscript.

\section{Acknowledgements}

Multi-channel seismic data were acquired by JAMSTEC. C. Moore (UCSC) and an anonymous reviewer provided constructive comments. This study was supported by a Grant-in-Aid for Scientific Research on Innovative Areas from the Japan Society for the Promotion of Science (JSPS) (21107003). T. Tsuji gratefully acknowledges the support of the International Institute for Carbon-Neutral Energy Research (WPI-I2CNER), sponsored by the World Premier International Research Center Initiative (WPI), MEXT, Japan.

\section{Author details}

${ }^{1}$ International Institute for Carbon-Neutral Energy Research (WPI-I2CNER), Kyushu University, 744 Motooka, Nishi-ku, Fukuoka 819-0395, Japan. ${ }^{2}$ Atmosphere and Ocean Research Institute, University of Tokyo, 5-1-5 Kashiwanoha, Kashiwa-shi, Chiba 277-8564, Japan. ${ }^{3}$ Department of Earth and Planetary Science, University of Tokyo, 7-3-1 Hongo, Bunkyo-ku, Tokyo 113-0033, Japan.

Received: 26 February 2014 Accepted: 9 September 2014 Published: 19 September 2014

\section{References}

Ando M (1975) Source mechanisms and tectonic significance of historical earthquake derived from tsunami data. Phys Earth Planet Inter 28:320-336

Anma R, Ogawa Y, Moore GF, Kawamrua K, Sasaki T, Kawakami S, Dilek Y, Michiguchi $Y$, Endo R, Akaiwa S, Hirano S (2011) Structural profile and development of the accretionary complex in the Nankai Trough, southwest Japan: results of submersible studies. In: Ogawa Y, Anma R, Dilek Y (ed) Accretionary prisms and convergent margin tectonics in the northwest Pacific basin. Springer, Dordrecht, pp 169-196. doi:10.1007/978-90-481-8885-7_8

Ashi J, Kuramoto S, Morita S, Tsunogai U, Goto S, Kojima S, Okamoto T, Ishimura T, ljiri A, Toki T, Kudo S, Asai S, Utsumi M (2002) Structure and cold seep of the Nankai accretionary prism off Kumano-outline of the off Kumano survey during YK01-04 Leg 2 cruise. JAMSTEC Deep Sea Res 20:1-8
Ashi J, Kinoshita M, Kuramoto S, Morita S, Saito S (2003) Seafloor gamma ray measurements around active faults by standalone system. JAMSTEC Deep Sea R 22:179-187

Ashi J, Lallemant S, Masago H (2007) NanTroSEIZE Stage 1. NanTroSEIZE megasplay riser pilot. Integrated Ocean Drill, Program Sci. Prospectus, p 315. doi:10.2204/iodp.sp.315.2007. http://publications.iodp.org/scientific_prospectus/ 315/315SP.PDF. Accessed 2010

Ashi J, Lallemant S, Masago H, the Expedition 315 Scientists (2008) NanTroSElZE Stage 1A: NanTroSElZE megasplay riser pilot. IODP Prel, Rept. doi:10.2204/ iodp.pr.315.2008. 315

Baba T, Cummins PR (2005) Contiguous rupture areas of two Nankai Trough earthquakes revealed by high-resolution tsunami waveform inversion. Geophys Res Lett 32:L08305. http://dx.doi.org/10.1029/2004GL022320

Bangs N, Moore G, Gulick S, Pangborn E, Tobin H, Kuramoto S, Taira A (2009) Broad, weak regions of the Nankai megathrust and implications for shallow coseismic slip. Earth Planet Sci Lett 284:44-49

Brown KM, Bekins B, Clennell B, Dewhurst D, Westbrook G (1994) Heterogeneous hydrofracture development and accretionary fault dynamics. Geology 22:259-262

Cartwright JA, Trudgill BD, Mansfield CS (1995) Fault growth by segment linkage: an explanation for scatter in maximum displacement and trace length data from the Canyonlands Grabens of SE Utah. J Struct Geol 17:1319-1326

Chang C, McNeill LC, Moore JC, Lin W, Conin M, Yamada Y (2010) In situ stress state in the Nankai accretionary wedge estimated from borehole wall failures. Geochem Geophys Geosyst 11:Q0AD04. doi:10.1029/2010GC003261

Dominguez S, Lallemand S, Malavieille J, Schnürle P (1998) Oblique subduction of the Gagua Ridge beneath the Ryukyu accretionary wedge system: insights from marine observations and sandbox experiments. Marine Geophys Res 20:383-402

Ellis M, Dunlap W (1988) Displacement variation along thrust faults: implications for the development of large faults. J Struct Geol 10:183-192

Gulick S, Bangs N, Moore G, Ashi J, Martin K, Sawyer D, Tobin HJ, Kuramoto S, Taira A (2010) Rapid forearc basin uplift and megasplay fault development from 3D seismic images of Nankai Margin off Kii Peninsula, Japan. Earth Planet Sci Lett 300:55-62. doi:10.1016/j.epsl.2010.09.034

Gulick SPS, Austin JA, McNeill LM, Bangs NL, Martin KM, Henstock TJ, Bull JM, Dean SM, Djajadihardja YS, Permana H (2011) Updip rupture of the 2004 Sumatra earthquake extended by thick indurated sediments. Nat Geosci 4:453

Gulick SPS, Bangs N, Shipley TH, Nakamura Y, Moore G, Kuramoto S (2004) Three-dimensional architecture of the Nankai accretionary prism's imbricate thrust zone off Cape Muroto, Japan: prism reconstruction via en echelon thrust propagation. J Geophys Res 109, B02105. doi:10.1029/2003JB002654

Hornafius JS, Luyendyk BP, Terres RR, Kamerling MJ (1986) Timing and extent of Neogene tectonic rotation in the western Transverse Ranges, California. GSA Bull 97:1476-1487

Ide S, Shiomi K, Mochizuki K, Tonegawa T, Kimura G (2010) Split Philippine Sea Plate beneath Japan. Geophys Res Lett 37, L21304. doi:10.1029/2010GL044585

Ikeda M, Toda S, Kobayashi S, Ohno Y, Nishizaka N, Ohno I (2009) Tectonic model and fault segmentation of the Median Tectonic Line active fault system on Shikoku, Japan. Tectonics 28, TC5006. doi:10.1029/2008TC002349

Ito T, Yoshioka S, Miyazaki S (1999) Interplate coupling in southwest Japan deduced from inversion analysis of GPS data. Phys Earth Planet Inter 115:17-34

Kamei R, Pratt RG, Tsuji T (2012) Waveform tomography imaging of a megasplay fault system in the seismogenic Nankai subduction zone. Earth Planet Sci Lett 317-318:343-353

Kamei R, Pratt RG, Tsuji T (2013) On acoustic waveform tomography of wideangle OBS data_-strategies for preconditioning and inversion. Geophys J Int. doi:10.1093/gji/ggt165

Kamei R, Pratt RG, Tsuji T (2014) On misfit function in Laplace-Fourier domain waveform inversion, with application to wide-angle ocean bottom seismograph data. Geophys Prospect, in press

Kikuchi M, Nakamura M, Yoshikawa K (2003) Source rupture processes of the 1944 Tonankai earthquake and the 1945 Mikawa earthquake derived from low gain seismograms. Earth Planets Space 55:159-172

Kimura J, Stern RJ, Yoshida T (2005) Reinitiation of subduction and magmatic responses in SW Japan during Neogene time. Geol Soc Am Bull 117:969-986. doi:10.1130/B25565.1

Kimura G, Kitamura Y, Hashimoto Y, Yamaguchi A, Shibata T, Ujiie K, Okamoto S (2007) Transition of accretionary wedge structures around the up-dip limit of the seismogenic subduction zone. Earth Planet Sci Lett 255:471-484

Kimura G, Moore GF, Strasser M, Screaton E, Curewitz D, Streiff C, Tobin H (2011) Spatial and temporal evolution of the megasplay fault in the Nankai Trough. Geochem Geophys Geosyst 12:Q0A008. doi:10.1029/2010GC003335 
Lin W, Doan ML, Moore JC, Mcneill L, Byrne T, Ito T, Saffer D, Conin M, Kinoshita M, Sanada Y, Moe KT, Araki E, Tobin H, Boutt D, Kano Y, Hayman NW, Flemings P, Huftile G, Cukur D, Buret C, Schleicher A, Efimenko N, Kawabata K, Buchs D, Jiang S, Kameo K, Horiguchi K, Wiersberg T, Kopf A, Kitada K, et al. (2010) Present-day principal horizontal stress orientations in the Kumano forearc basin of the southwest Japan subduction zone determined from IODP NanTroSEIZE drilling Site C0009. Geophys Res Lett 37, L13303. doi:10.1029/2010GL043158

Maruyama T (1969) Stress fields in the neighborhood of a crack. Bull Earthq Res Inst, Univ Tokyo 47:1-29

Martin KM, Gulick SPS, Bangs NLB, Moore GF, Ashi J, Park JO, Kuramoto S, Taira A (2010) Possible strain partitioning structure between the Kumano fore-arc basin and the slope of the Nankai Trough accretionary prism. Geochem Geophys Geosyst 11:Q0AD02. doi:10.1029/2009GC002668

Martinez A, Malavieille J, Lallemand S, Collot JY (2002) Strain partitioning in an accretionary wedge in oblique convergence: analogue modeling. Bull Soc géol France 173:17-24

McCaffrey R, Zwick PC, Bock Y, Prawirodirdjo L, Genrich JF, Stevens CW, Puntodewo SSO, Subarya C (2000) Strain partitioning during oblique plate convergence in northern Sumatra: geodetic and seismologic constraints and numerical modeling. J Geophys Res 105(B12):28,363-28,376. doi:10.1029/ 1999JB900362

Miyazaki S, Heki K (2001) Crustal velocity field of southwest Japan: subduction and arc-arc collision. J Geophys Res 106:4305-4326

Moeremans R, Singh SC, Mukti M, McArdle J, Johansen K (2014) Seismic images of structural variations along the deformation front of the Andaman-Sumatra subduction zone: implications for rupture propagation and tsunamigenesis. Earth Planet Sci Lett 386:75-85

Moore GF, Park JO, Bangs NL, Gulick SP, Tobin HJ, Nakamura Y, Sato S, Tsuji T, Yoro T, Tanaka H, Uraki S, Kido Y, Sanada Y, Kuramoto S, Taira A (2009) Structural and seismic stratigraphic framework of the NanTroSElZE Stage 1 transect. Proc IODP 314:315-316. doi:10.2204/iodp.proc.314315316.102

Murphy JM, Fuis GS (2010) Detailed P- and S-wave velocity models along the LARSE II transect, southern California. Bull Seismolog Soc Am 100:3194-3212

Park J, Tsuru T, Kodaira S, Cummins PR, Kaneda Y (2002) Splay fault branching along the Nankai subduction zone. Science 297:1157-1160

Park J, Kodaira S (2012) Seismic reflection and bathymetric evidences for the Nankai earthquake rupture across a stable segment-boundary. Earth Planets Space 64:299-303

Satake K (1994) Mechanism of the 1992 Nicaragua tsunami earthquake. Geophys Res Lett 21:2519-2522

Seno T, Stein S, Gripp AE (1993) A model for the motion of the Philippine Sea Plate consistent with NUVEL-1 and geological data. J Geophys Res 98:17,941-17,948

Seno T, Maruyama S (1984) Paleogeographic reconstruction and origin of the Philippine Sea. Tectonophysics 102:53-84. doi:10.1016/0040-1951(84)90008-8

Strasser M, Moore GF, Kimura G, Kitamura Y, Kopf AJ, Lallement S, Park JO, Screaton E, Su X, Underwood MB, Zhao X (2009) Origin and evolution of a splay fault in the Nankai accretionary wedge. Nat Geosci 2:648-652. doi:10.1038/ngeo609

Subarya C, Chlieh M, Prawirodirdjo L, Avouac J-P, Bock Y, Sieh K, Meltzner AJ, Natawidjaja DH, McCaffrey R (2006) Plate-boundary deformation associated with the great Sumatra-Andaman earthquake. Nature 440:46-51. doi:10.1038/ nature 04522

Takahashi M (2006) Tectonic development of the Japanese Islands controlled by Philippine Sea Plate motion. J Geography (Chigaku Zasshi) 115:116-123

Taner MT, Koehler F, Sheriff RE (1979) Complex seismic traces analysis. Geophysics 44:1041-1063

Tanioka Y, Satake K (2001) Detailed coseismic slip distribution of the 1944 Tonankai earthquake estimated from tsunami waveforms. Geophys Res Lett 28:1075-1078

Tobin H, Kinoshita M, Moe KT, the Expedition 314 Scientists (2009) Expedition 314 summary. In: Kinoshita M, Tobin H, Ashi J, Kimura G, Lallemant S, Screaton EJ, Curewitz D, Masago H, Moe KT, and the Expedition 314/315/316 Scientists. Proc Integr Ocean Drill Program, 314/315/316, Washington, DC (Integr Ocean Drill Program Management International, Inc.). doi:10.2204/ iodp.proc.314315316.111.2009

Toki T, Tsunogai U, Gamo T, Kuramoto S, Ashi J (2004) Detection of low-chloride fluids beneath a cold seep field on the Nankai accretionary wedge off Kumano, south of Japan. Earth Planet Sci Lett 228:37-47
Tsuji T, Kawamura K, Kanamatsu T, Kasaya T, Fujikura K, Ito Y, Tsuru T, Kinoshita M (2013) Extension of continental crust by anelastic deformation during the 2011 Tohoku-oki earthquake: the role of extensional faulting in the generation of a great tsunami. Earth and Planet Sci Lett 364:44-58. doi:10.1016/j.epsl.2012.12.038

Tsuji T, Dvorkin J, Mavko G, Nakata N, Matsuoka T, Nakanishi A, Kodaira S, Nishizawa O (2011a) Vp/Vs ratio and shear-wave splitting in the Nankai Trough seismogenic zone: insights into effective stress, pore pressure and sediment consolidation. Geophysics 76:WA71-WA82

Tsuji T, Hino R, Sanada Y, Yamamoto K, Park JO, No T, Araki E, Bangs N, von Huene R, Moore G, Kinoshita M (2011b) In situ stress state from walkaround VSP anisotropy in the Kumano basin southeast of the Kii Peninsula, Japan. Geochem Geophys Geosyst 12:Q0AD19. doi:10.1029/2011GC003583

Tsuji T, Kimura G, Okamoto S, Kono F, Mochinaga H, Saeki T, Tokuyama H (2006) Modern and ancient seismogenic out-of-sequence thrusts in the Nankai accretionary prism: comparison of laboratory-derived physical properties and seismic reflection data. Geophys Res Letts 33, L18309. doi:10.1029/ 2006GL027025

Tsuji T, Matsuoka T, Yamada Y, Nakamura Y, Ashi J, Tokuyama H, Kuramoto S, Bangs N (2005) Initiation of plate boundary slip in the Nankai Trough off the Muroto peninsula, southwest Japan. Geophys Res Lett 32, L12306. doi:10.1029/2004GL021861

Tsuji T, Kamei R, Pratt G (2014) Pore pressure distribution of a mega-splay fault system in the Nankai Trough subduction zone: insight into up-dip extent of the seismogenic zone. Earth Planet Sci Lett 396:165-178

Tsuru T, Miura S, Park JO, Ito A, Fujie G, Kaneda Y, No T, Katayama T, Kasahara J (2005) Variation of physical properties beneath a fault observed by a two-ship seismic survey off southwest Japan. J Geophys Res 110, B05405. doi:10.1029/2004JB003036

Wang K, Hu Y (2006) Accretionary prisms in subduction earthquake cycles: the theory of dynamic Coulomb wedge. J Geophys Res 111, B06410. doi:10.1029/ 2005JB004094

Westbrook GK (1994) Growth of accretionary wedges off Vancouver island and Oregon. In: Westbrook GK, Carson B, Musgrave RJ, et al. (eds) Proceedings of the Ocean Drilling Program, Initial Reports, College Station. TX (Ocean Drilling Program) 146:381-388

Woodcock NH (1986) The role of strike-slip fault systems at plate boundaries. Phil Trans R Soc Lond 317:13-29

Yamada Y, Baba K, Matsuoka T (2006) Analogue and numerical modelling of accretionary prisms with a decollement in sediments. In: Buiter S, Scherurs G (ed) Numerical and analogue modelling of crustal-scale processes, Geological Society Special Publication, vol 253. Geological Society, London, pp 169-183

Yamada Y, Masui R, Tsuji T (2013) Characteristics of a tsunamigenic megasplay fault in the Nankai Trough. Geophys Res Lett 20:4594-4598. doi:10.1002/grl.50888

Yilmaz O, Doherty S (ed) (2001) Seismic data processing, 2nd edn. Invest. in Geophys, SEG, Tulsa

doi:10.1186/1880-5981-66-120

Cite this article as: Tsuji et al:: Strike-slip motion of a mega-splay fault system in the Nankai oblique subduction zone. Earth, Planets and Space 2014 66:120.

\section{Submit your manuscript to a SpringerOpen ${ }^{\circ}$ journal and benefit from:}

- Convenient online submission

$\checkmark$ Rigorous peer review

- Immediate publication on acceptance

- Open access: articles freely available online

- High visibility within the field

- Retaining the copyright to your article

Submit your next manuscript at $>$ springeropen.com 